
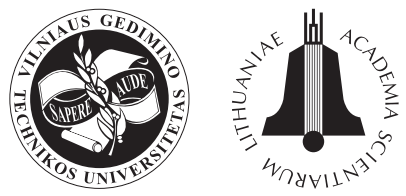

TRANSPORT

24(4): 345-351

\title{
CARRIER'S LIABILITY UNDER INTERNATIONAL MARITIME CONVENTIONS AND THE UNCITRAL DRAFT CONVENTION ON CONTRACTS FOR THE INTERNATIONAL CARRIAGE OF GOODS WHOLLY OR PARTLY BY SEA
}

\author{
Su Tong-jiang ${ }^{1}$, Wang Peng ${ }^{2}$ \\ ${ }_{1,2}$ Qingdao Ocean Shipping Mariners College, Qingdao 266071, China \\ ${ }^{2}$ School of Management, Xian Jiaotong University, Xian 710049, China \\ E-mail:sutongjiang1@yahoo.com.cn
}

Received 11 October 2008; accepted 3 November 2009

\begin{abstract}
The UNCITRAL Draft Convention on Contracts for the International Carriage of Goods Wholly or Partly by Sea was approved on Thursday, 3 July 2008 and would then be presented to the General Assembly of the United Nations for endorsement later this year. Many innovative features contained in the Draft Convention fill the perceived gaps in existing transport regimes. Carrier's liability compared with international maritime conventions and the Draft Convention as well as China Maritime Code is discussed in the paper. It is pointed out that although the Draft Convention plays a very important role in the development of international private maritime law regime, the entry into the force of the Draft Convention is not optimistic.
\end{abstract}

Keywords: draft convention, carrier's liability, hague-visby rules, Hamburg rules, CMC.

\section{Introduction}

Nowadays, the international carriage of goods by sea (Faghfouri 2008; Paulauskas and Bentzen 2008; Lingaitiene 2008; Afandizadeh and Moayedfar 2008) is governed by various conventions such as the International Convention for the Unification of Certain Rules of Law Relating to Bills of Lading (the Hague Rules), Protocol to Amend the International Convention for the Unifcation of Certain Rules Relating to Bills of Lading 1924, (the Hague-Visby Rules) 1968, 1979; United Nations Convention on the Carriage of Goods by Sea, 1978 (the Hamburg Rules). These Rules established minimum obligations, maximum immunities and the limit of carrier's liability and aims at creating one uniform law concerning the international carriage of goods by sea. Nevertheless, none of these attempts has been successful, instead, the present legal framework consists of a disordered array of international conventions designed to regulate the carriage of goods by sea, diverse regional/sub-regional agreements, national laws and standard term contracts. As a consequence, both the applied liability rules and the degree and extent of carrier's liability vary greatly from case to case and are unpredictable. Modern transport patterns and practices have been considerably affected by the growth of containerized transportation together with technological developments on the mul- timodal transferring systems (Tolli and Laving 2007; Jaržemskienè 2007; Vasilis Vasiliauskas and Barysienè 2008; Afandizadeh and Moayedfar 2008; Jaržemskiené and Jaržemskis 2009; Liu et al. 2009). Increasingly, big liner shipping companies, some of which dominate the container shipments of ocean trade, are also expanding their services to offer transportation from door-to-door by involving other carriers to perform different modal stages of a multimodal transaction (Jaržemskienè and Jaržemskis 2009; Burkovskis 2008; Lingaitienè 2008; Jaržemskis and Vasilis Vasiliauskas 2007). The current liability framework reflects few developments that have taken place in terms of transport patterns, technology and markets. The international uniform regime has not been in force to govern liability for loss, damage or delay arising from multimodal transport.

In 1996, considering the absence of an updated maritime transport regime, the United Nations Commission on International Trade Law (UNCITRAL) proposed to include a review of modern practices and applicable law regimes in the international carriage of goods by sea in its work program with a view of establishing the need for uniform rules where such rules were lacking so as to achieve greater uniformity of laws (Tetley 2003). Accordingly, it assigned to the Secretariat the task of collecting information, ideas and opinions 
from governments and international organizations representing commercial sectors involved in the carriage of goods by sea.

Subsequently, the International Maritime Committee (CMI, Comité Maritime International) collaborated in this task and after three and a half years of work, during which two additional drafts were authored, the CMI delivered to the UNCITRAL the CMI Draft Instrument on Transport Law. Since 2002, UNCITRAL's Working Group on Transport Law has been working in close cooperation with interested international inter-governmental and non-governmental organizations to prepare a legislative text on the issues relating to the international carriage of goods (Faghfouri 2008). The Draft Convention was prepared over thirteen sessions from April 2002 to January 2008, and finally the UNCITRAL was approved on Thursday, 3 July, 2008 as the Draft Convention on Contracts for the International Carriage of Goods Wholly or Partly by Sea (hereinafter 'the Draft Convention'). The Draft Convention would then be presented to the General Assembly of the United Nations for endorsement later this year (see Report of the United Nations Commission on International Trade Law 2008).

The following provides a brief account of carrier's liability based on international maritime conventions and the revised text of the Draft Convention annexed to the report of the Working Group in the document report of the Working Group: A/CN.9/645 (Faghfouri 2008).

\section{Comparison of Carrier's Liability under International Maritime Conventions}

The carrier's liability regime directly regulates the allocation of risks between the carrier and cargo interests. In maritime judicial practice, most cases involve disputes concerning whether the carrier shall be liable for the loss of or damage to the goods and the scope of carrier's liability. Thus, the carrier's liability regime set in international maritime conventions has a close impact on the developments of international shipping industry and international trade. In this sense, the carrier's liability regime is the core and bedrock in the legal system of the international carriage of goods by sea. Currently, there are three international conventions in force governing international maritime transport: the Hague Rules, the Hague-Visby Rules and the Hamburg Rules. The Rules established minimum obligations, maximum immunities and the limit of carrier's liability. The main differences among these Rules and Draft Conventions are described as the following.

\subsection{The Period of Carrier's Responsibility}

The Hague Rules and Hague-Visby Rules apply that according to Article 1(e), this period lasts 'from the time when the goods are loaded on to the time when they are discharged from the ship. This classic rule is better known as 'tackle to tackle. It traditionally meant from the moment when a ship's tackle is hooked on at the loading port until the moment when the ship's tackle is unhooked at discharge. Although this is the classic term describing the limits of applying the Rules, the
Hague Rules and the Hague-Visby Rules are available to the whole contract of carriage, including the entire loading and discharging if the parties so agree. Article 7 of both Rules provides that 'Nothing herein contained shall prevent a carrier or a shipper from entering into any agreement, stipulation, condition, reservation or exemption as to the responsibility and liability of the carrier or the ship for the loss or damage to, or in connection with, the custody and care and handling of goods prior to the loading on, and subsequent to, the discharge from the ship on which the goods are carried by sea. In other words the period of application may be extended beyond tackle to tackle by the terms of the bill of the lading contract.

According to Article 4.1 of the Hamburg Rules, the period of the responsibility of the carrier for the goods covers the period during which the carrier is in charge of the goods at the port of loading during the carriage and at the port of discharge. This encompasses the period from port to port and accordingly increases the liability of the carrier. This is to solve the problem of responsibility during cargo handling in the port, which is unclear under the Hague Rules and the Hague-Visby Rules. A simple meaning of who is in charge of the goods is given in Article 4(2) (a)(ii) of the Hamburg Rules, - the carrier is not responsible until he receives the goods from the port authority or other third party pursuant to law or regulation. At delivery, in the virtue of Article $4(2)$ (b) (ii), there is an even a broader meaning applied to the carrier by handling over the goods to the port authority or other third party pursuant to law or regulation; incasing where the consignee does not receive the goods from carrier, by placing them at the disposal of the consignee in accordance with the contract or with the law or with the usage of the particular trade, which is applicable at the port of discharge.

According to the Article 12.1 of the Draft Convention, the period of responsibility of the carrier for the goods begins when the carrier or a performing party receives the goods for carriage and ends when the goods are delivered. It further prolongs the period of the liability of the carrier to any place beyond the port. Draft Convention Article 12.2 stipulates that:

(a) if the law or regulations of the place of receipt require the goods to be handed over to an authority or other third party from which the carrier may collect them, the period of responsibility of the carrier begins when the carrier collects the goods from the authority or other third party;

(b) if the law or regulations of the place of delivery require the carrier to hand over the goods to an authority or other third party from which the consignee may collect them, the period of responsibility of the carrier ends when the carrier hands the goods over to the authority or other third party.

An overview over the relevant period of carrier's liability is provided in Table 1. 
Table 1. Overview over the relevant period of carrier's liability

\begin{tabular}{cccc}
\hline Hague Rules & $\begin{array}{c}\text { Hague-Visby } \\
\text { Rules }\end{array}$ & $\begin{array}{c}\text { Hamburg } \\
\text { Rules }\end{array}$ & $\begin{array}{c}\text { Draft } \\
\text { Convention }\end{array}$ \\
\hline $\begin{array}{c}\text { Tackle to } \\
\text { tackle }\end{array}$ & $\begin{array}{c}\text { Tackle to } \\
\text { tackle }\end{array}$ & Port to port & Place to place \\
\hline
\end{tabular}

\subsection{Basis of Carrier's Liability}

Except for the particular defenses of error in the navigation and management of the ship and fire, the basis of liability applicable to the carrier under the Hague Rules and the Hague-Visby Rules comes to a liability for presumed fault or neglect plus exceptions, which means that the carrier has an obligation to exercise due diligence to make the ship in all respects seaworthy so that it can properly carry the goods to destination. The carrier shall be liable for loss or damage arising or resulting from unseaworthiness causes by the want of due diligence. The Hague Rules and the Hague-Visby Rules contain a catalogue of the exceptions of liability.

The general principle on carrier's liability set out under the Hamburg Rules is based on presumed fault, according to Article 5.1 which stipulated that the carrier is liable for loss resulting from the loss of or damage to the goods as well as for delay in delivery if occurrence that causes the loss, damage or delay took place while the goods were in his charge as defined in Article 4, unless the carrier proved that he, his servants or agents had taken all reasonable measures required to avoid the occurrence and its consequences. There would be no exemption in case of fault of the carrier's servants or agents in the course of the navigation or management of the vessel under the Hamburg Rules.

Carrier's liability under the Draft Convention is also based on presumed fault, according to Article 18(1). If the claimant proves that the loss, damage, or delay, or the event or circumstance that caused or contributed to it took place during the period of carrier's responsibility as defined in Chapter 4, the carrier is liable for loss of or damage to the goods as well as for delay in delivery. And Article 18(2) also stipulates that the carrier is relieved of all or part of its liability pursuant to Paragraph 1 of this article if it proves that the cause or one of the causes of the loss, damage, or delay is not attributable to its fault or to the fault of any person referred to in Article 19.

Article 18 of the Draft Convention has absorbed both the Hague-Visby Rules and the Hamburg Rules structure that the exception of nautical fault has been deleted and sets a list of exceptions somewhat similar to that of the Hague-Visby Rules with the addition of some new exceptions that have been maintained. While carrier's seaworthiness obligation is made a continuous obligation, there are more rights and exceptions in favour of the carrier (see Articles 16 and 17 and relevant exceptions in Article18(3)). There are also a number of provisions which effectively permit the carrier's possibility of contracting out by limiting contractually the period of responsibility (Article 12(3)) or functions for which the carrier may not be responsible (Article 14(2)) and be acting as an agent for some parts of transport (Article 13) (Faghfouri 2008).

\subsection{Allocation of the Burden of Proof and Allocation of Liability in Cases of Concurrent Causes}

The issues are both important and complex on how to regulate the burden of proof and the allocation of liability in cases of concurrent causes. The legal burden of proof is a technical legal concept leading to an important practical dilemma, namely: if two parties do not agree with each other, who should produce the necessary prove? In relation to any legal dispute this is a matter of great significance that may affect the outcome of the dispute. This is particularly true in cases where evidence is difficult to obtain. The party bearing the burden of proof with regard to a particular issue or argument needs to provide relevant evidence. In case it cannot, it will have to accept defeat on the issue in question. Thus, whoever bears the burden of proof bears the risk associated with a lack of evidence. In relation to loss arising from the international carriage of goods by sea, evidence about the causes of loss will often be difficult to obtain, particularly for cargo consignee or shipper who may not have access to any of the relevant facts. Moreover, the loss, damage or delay of cargo during transit are often due to a combination of factors and, in these cases, evidence about the extent to which different identified causes have contributed to a loss may be even more difficult to find. Against this background, it is clear that rules on the allocation of the burden of proof as between carrier and cargo interests are crucial to the overall allocation of risk as between the two parties (UNCTAD 2004).

Under the Hague Rules and Hague-Visby Rules as well as under the Hamburg Rules, once a cargo claimant has established a loss, the burden of proof in relation to the causes of the loss is on the carrier. This is generally recognized. In the absence of sufficient evidence of the cause(s) of a loss, the carrier will be responsible for the (whole) loss. The carrier is therefore generally liable in cases of the unexplained losses. In cases where there is a combination of causes, the carrier is liable for the whole loss, unless it can prove the extent to which a quantifiable proportion of the loss was solely due to a cause for which he is not responsible (UNCTAD 2004).

There are more detailed rules on the burden of proof that significantly differ from the existing transport conventions and constitute a major shift in risk allocation in favour of the carrier (Faghfouri 2008).

Article 18.4 stipulates that 'the carrier is liable for all or part of the loss, damage, or delay:

(a) if the claimant proves that the fault of the carrier or of a person referred to in Article 19 caused or contributed to the event or circumstance on which the carrier relies;

(b) if the claimant proves that an event or circumstance not listed in Paragraph 3 of this Article contributed to the loss, damage or delay and the carrier cannot prove that this event or circumstance is not attributable to its fault or to the fault of any person referred to in Article 19'. 
Article 18.5 also stipulates that 'the carrier is also liable for all or part of the loss, damage or delay if:

(a) the claimant proves that the loss, damage or delay was or was probably caused by or contributed to by:

(i) the unseaworthiness of the ship;

(ii) the improper crewing, equipping and supplying of the ship;

(iii) the fact that the holds or other parts of the ship in which the goods are carried (including any containers supplied by the carrier in or upon which the goods are carried) were not fit and safe for reception, carriage and preservation of the goods;

(b) the carrier is unable to prove either that:

(i) none of the events or circumstances referred to in Subparagraph 5(a) of this article caused the loss, damage or delay;

(ii) that it complied with its obligation to exercise due diligence pursuant to Article 15.

\subsection{Limits of Liability}

All transport law conventions currently in force provide for the monetary limitation of liability but the relevant levels vary considerably. Under the Hague Rules, the limits of liability for the carrier are $£ 100$ per package or unit unless the nature and value of goods have been declared by the shipper before shipment and inserted in the bill of lading. Under the Hague-Visby Rules, the limits of the liability of the carrier for the loss of or damage to the goods reach an amount equivalent to 666.67 SDR per package or other shipping unit, or 2 SDR per kilogram of the gross weight of the goods lost or damaged, whichever is higher, unless the nature and value of the goods have been declared by the shipper and inserted in the bill of lading or a higher limit has been agreed upon between the carrier and the shipper. The Hamburg Rules are provided for a dual system similar to those given in the Hague-Visby Rules but the amount is much higher than its. Carrier's liability under the Hamburg Rules is limited to an amount equal to 835 SDR per package or other shipping unit or 2.5 SDR per kg of gross weight, whichever is higher. Both the Hague-Visby Rules and the Hague-Visby Rules are lacking in provisions expressly regulating carrier's liability for delay. Under the Hamburg Rules, in case of delayed goods, carrier's liability is limited to an mount equivalent to 2.5 times of the freight payable for the goods delayed but not exceeding the total sum of the freight payable under the respective contract of carriage by sea.

The agreement on the monitory limitation of carriers' liability was a part of a compromise package under the Draft Convention in Article 61 which stipulated that carrier's liability for the breaches of its obligations under this Convention is limited to 875 units of account per package or other shipping unit, or 3 units of account per kilogram of the gross weight of the goods that are the subject of the claim or dispute, whichever amount is higher, except when the value of the goods has been declared by the shipper and included in the contract particulars, or when a higher amount than the amount of limitation of liability set out in this article has been agreed upon between the carrier and the shipper. In case of delayed goods, carrier's liability is similar to those in the Hamburg Rules.

An overview over the relevant amounts is provided in Table 2.

Table 2. Overview over the relevant amounts

\begin{tabular}{llll}
\hline Hague Rules & $\begin{array}{c}\text { Hague-Visby } \\
\text { Rules }\end{array}$ & $\begin{array}{c}\text { Hamburg } \\
\text { Rules }\end{array}$ & $\begin{array}{c}\text { Draft } \\
\text { Convention }\end{array}$ \\
\hline \multirow{4}{*}{100 per } & 2 SDR per & 2.5 SDR per & 3 SDR per \\
package & 666.67 per & $\begin{array}{l}\text { kilogram or } \\
\text { 835 SDR per } \\
\text { package }\end{array}$ & $\begin{array}{l}\text { 875 SDR per } \\
\text { package }\end{array}$ \\
& package \\
\hline
\end{tabular}

\section{Carrier's Liability under China Maritime Code}

In China, the law specially dealing with international maritime transport is contained in the Maritime Code of the People's Republic of China (CMC) consisting of 15 chapters and totally 278 articles. CMC, enacted in 1992 and coming into effect on 1 July 1993, is the most important law governing maritime relations. Chapter 4 deals with the contract of carrying goods by sea with much reference to the international conventions, customs and practices. It can be said that the regulations governing the contract of carrying goods by sea are mostly made-out on the basis of the Hague Rules, the Hague-Visby Rules and appropriately refer to the Hamburg Rules as well.

\subsection{Period of Carrier's Responsibility}

Unlike the international maritime conventions (), the period of carrier's responsibility is divided on the basis of container cargo and non-containerized cargo. According to Article 46 of CMC, the responsibilities of the carrier with regard to the goods carried in containers covers the entire period during which the carrier is in charge of the goods starting from the time the carrier has taken over the goods at the port of loading until the goods have been delivered at the port of discharge. The responsibility of the carrier with respect to noncontainerized goods covers the period during which the carrier is in charge of the goods starting from the time of loading the goods onto the ship until the time the goods are discharged there from. During the period the carrier is in charge of the goods, the carrier shall be liable for the loss of or damage to the goods, except as otherwise provided for in this Section.

\subsection{Basis of Carrier's Liability}

Like the Hague Rules and the Hague-Visby Rules, the basis of liability applicable to the sea carrier under CMC comes very close to a liability for presumed fault or neglect except for the particular defenses of error in the navigation and management of the ship and fire. 


\subsection{Allocation of the Burden of Proof and Allocation of Liability in Cases of Concurrent Causes}

The burden of proof under CMC rests on the carrier except for fire as stipulated in Article 51: 'The carrier who is entitled to exoneration from the liability for compensation as provided for in the preceding paragraph shall, with the exception of the causes given in Subparagraph ( 2 fire), bear the burden of proof'.

In cases of concurrent causes, Article 54 of CMC stipulated that where loss or damage or delay in delivery has occurred from causes from which the carrier or his servant or agent is not entitled to exoneration from liability, together with another cause, the carrier shall be liable only to the extent that the loss, damage or delay in delivery is attributable to the causes from which the carrier is not entitled to exoneration from liability; however, the carrier shall bear the burden of proof with respect to the loss, damage or delay in delivery resulting from the other cause.

\subsection{Limits of Liability}

Article 56 limits the liability of the carrier for the loss of or damage to the goods to an amount equivalent to 666.67 SDR per package or other shipping unit, or 2 SDR per kilogram of the gross weight of the goods lost or damaged, whichever is higher, unless the nature and value of the goods have been declared by the shipper and inserted in the bill of lading, or a higher limit has been agreed upon between the carrier and the shipper.

Carrier's liability for economic loss resulting from delay in delivering goods is limited to an amount equivalent to freight payable for the goods so delayed (Article 57). The carrier, however, is not entitled to limit his liability if it is proved that the loss, damage or delay in delivery resulted from his act or omission done with the intent to cause such loss, damage or delay or recklessly and with knowledge that such loss, damage or delay would probably result (Article 59).

\section{The Prospect of the Draft Convention}

The Draft Convention serves as a major international transport law convention in the 21 st century and is expected to replace the existing maritime conventions namely the Hague Rules, the Hague-Visby Rules and the Hamburg Rules. The Draft Convention aims at creating a modern and uniform law concerning the international carriage of goods which include an international sea leg but is not limited to the port-to-port carriage of goods and has already in essence exceeded the scope of other maritime conventions such as the Hague Rules, the Hague-Visby Rules and the Hamburg Rules and become a special multimodal Convention. However, the prospect of the Draft Convention is not optimistic.

The question, however, is how successful will the Draft Convention be in achieving its very ambitious objectives? Although the formulation of the unified field of international regulations may be desirable, any successful new international liability regime must provide more obvious benefits than the existing legal framework.
Unfortunately, the Draft Convention only increases the complexity of the present but does not provide any benefits. The Draft Convention is obviously not made to take these factors into consideration. Irrespective of the provisions of the Draft Convention of the substantive merits, it does not produce the uniform standards of liability to transport at all stages. Because of liability management to take such a 'network' approach, door-to-door transactions in the determination of liability issues will continue to be involved in a particular jurisdiction and special circumstances that could be applied in a specific system. It is difficult to see how the current regulatory framework will improve on these methods. At present, there are various international maritime conventions governing sea transport. The process for joining the 1978 Hamburg Rules has been slow from the very time of their adoption (Tetley 2000) by UNCITRAL in 1978. The ratification of the Hamburg Rules demonstrates the same divergence because most of 34 countries that have become the parties of the Hamburg Rules thus far are the nations of the developing world. Adding a new treaty is unlikely to make greater harmony of laws. On the other side, new laws would increase the risk of disharmony.

The text and structure of the Draft Convention is unnecessarily complex and confusing and it seems not taking into account the need to ensure that international uniform rules is easy to understand and applicable. The Draft Convention is extremely lengthy and complex (98 articles) and varies significantly from the existing transport conventions both in substance, text and structure. Many of these provisions are complex with too many cross references. Therefore, the current number of the provisions of the Convention is large. The content is also very complicated. Quite a number of legal expertises are needed to understand these provisions and the proposed wording having a great room for different interpretation. In many cases, lengthy and costly litigation may be required to clarify the meaning of the relevant provisions and the scope of application. An undesirable result is unavoidable in explaining the proposed regulations because the existing States clearly have a large number of differences. Therefore, although the current draft convention does not fully resolve or deal with the problem of providing modern solutions, it at least made a useful and fruitful attempt. However, because of the above discussed deficiencies within the draft, for wider acceptance of the international community, more international transportation practices are to be made for the further development of it. The international community, particularly relevant interest groups must conduct an extensive in-depth discussion and amendments. Whatsoever, there is no doubt that the contents of the draft will cause more in-depth study on the Carriage of Goods by Sea by the international community which will further be unified with a profound impact.

Article 96 of the Draft Convention requires twenty Contracting States to enter into force. The ratifying States need to denounce any other sea transport conventions to which they are parties and the entry into 
force of the Draft Convention has been made conditional on the denunciation of the previous conventions. It is doubtful that the Contracting States of either the HagueVisby Rules or the Hamburg Rules will denounce the international maritime convention well-known for them and ratify a new convention which is a special new legal regime under which the new principles of law and the new language, clauses and phrases are not clear or familiar to judges, needless to say the main maritime players such as carrier, shipper, consignee, forwarder and relative parties.

In regard of the history of entry into force of international maritime conventions and other transport conventions, the Draft Convention still has a long way to go. The Hague Rules adopted in August 1924 entered into force in 1931. The Hague-Visby Rules adopted in 1968 entered into force in June 1977. The Hamburg Rules were adopted in March 1978, although with 68 votes in favour, non against and 3 abstentions, entered into force in November 1992. The United Nations Convention on International Multimodal Transport of Goods (MT Convention) was adopted in 1980 but did not attract the necessary number of ratifications and thus has not entered into force up to now. The Convention on the Contract for the International Carriage of Goods by Road (CMR) was adopted in May 1956 and entered into force in July 1961. The Protocol of 3 June 1999 for the Modification of the Convention concerning International Carriage by Rail (COTIF) of 9 May 1980 entered into force in July 2006.

These are a few examples of the international conventions related to transport by air: Convention for the Unification of Certain Rules Relating to International Carriage by Air (Warsaw Convention) was adopted in 1929 and entered into force in 1933, the Hague Protocol (1955) was adopted in1955 and entered into force in 1963, Montreal Protocol No 4 (1975) was adopted in 1975 but entered into force in 1998, Convention for the Unification of Certain Rules for International Carriage by Air (the Montreal Convention) replacing Warsaw Convention system of 1929 came into force on 4 November 2003.

\section{Conclusions}

1. The period of carrier's responsibility has been prolonged with the development of international maritime conventions form 'tackle to tackle' under the Hague Rules and the Hague-Visby Rules from port to port under the Hamburg Rules till place to place under the Draft Convention. It means that carrier's liability by the carriage of goods by sea has been increased step by step.

2. The basis of carrier's liability under the Hague Rules and the Hague-Visby Rules is presumed fault or neglect plus exceptions. Carrier's liability under Hamburg Rules and the Draft Convention are also based on presumed fault with the exception of deleted nautical fault.

3. The amount of the limits of the liability increased also with the development of international maritime conventions. Under the Hague Rules, the limits of liability for carrier is $£ 100$ per package or unit; un- der the Hague-Visby Rules, the limits of liability is an amount equivalent to 666.67 SDR per package, or 2 SDR per kilogram; the Hamburg Rules is to 835 SDR per package or 2.5 SDR per kg of gross weight; the Draft Convention is limited to 875 units of account per package or other shipping unit, or 3 units of account per kilogram of the gross weight of the goods.

4. The Draft Convention serves as a major international transport law convention in the 21st century and will give an impact to existing maritime convention and national laws referring to the carriage of goods by sea. However, the prospect of the Draft Convention is not optimistic, for it is extremely lengthy and complex and seems not to promote its uniform interpretation and application in different jurisdictions. It might be yet another convention adding further to the existing non-unified law of the international carriage of goods by sea as the example of the Hamburg Rules as well as MT Convention.

\section{References}

Afandizadeh, Sh.; Moayedfar, R. 2008. The feasibility study on creation of freight village in Hormozgan province, Transport 23(2): 167-171. doi:10.3846/1648-4142.2008.23.167-171

Burkovskis, R. 2008. Efficiency of freight forwarder's participation in the process of transportation, Transport 23(3): 208-213. doi:10.3846/1648-4142.2008.23.208-213

Comité Maritime International (CMI). 2009. Available from Internet: <http://www.comitemaritime.org >.

Convention on the Contract for the International Carriage of Goods by Road (CMR). Geneva, 19 May 1956. Available from Internet: <http://www.jus.uio.no/lm/un.cmr.road.carriage.contract.convention.1956/portrait.pdf>.

Convention for the Unification of Certain Rules for International Carriage by Air Montreal, 28 May 1999. Available from Internet: <http://www.jus.uio.no/lm/air.carriage.unification. convention.montreal.1999/portrait.pdf >.

Convention for the Unification of Certain Rules Relating to International Carriage by Air, Signed at Warsaw on 12 October 1929 (Warsaw Convention 1929). Available from Internet: <http://www.jus.uio.no/lm/air.carriage.warsaw.convention.1929/portrait.pdf>.

COTIF - Convention concerning International Carriage by Rail of 9 May 1980. Available from Internet: <http://www.otif. org/pdf_external/e/cotif-1980-reserves-e.PDF $>$.

Faghfouri, M. 2008. Overview of the UNCITRAL Draft Convention on Contracts for the International Carriage of Goods Wholly or Partly by Sea, IMMTA-News 1: 4-6. Available from Internet: <http://www.immta.org/uploads/ IMMTANews-2008-1.pdf>.

Jaržemskienè, I. 2007. The evolution of intermodal transport research and its development issues, Transport 22(4): 296-306.

Jaržemskienè, I.; Jaržemskis, V. 2009. Allotment booking in intermodal transport, Transport 24(1): 37-41. doi:10.3846/1648-4142.2009.24.37-41

Jaržemskis, A.; Vasilis Vasiliauskas, A. 2007. Research on dry port concept as intermodal node, Transport 22(3): 207-213.

Lingaitienè, O. 2008. A mathematical model of selecting transport facilities for multimodal freight transportation, Transport 23(1): 10-15. doi:10.3846/1648-4142.2008.23.10-15

Liu, W.; Xu, H.; Zhao, X. 2009. Agile service oriented shipping companies in the container terminal, Transport 24(2): 143-153. doi:10.3846/1648-4142.2009.24.143-153 
Maritime Code of the People's Republic of China. 1992. Available from Internet: <http://www.cosco.com/en/pic/research/025109361827329146.pdf>.

Montreal Protocol No.4 to Amend Convention for the Unification of Certain Rules Relating to International Carriage by Air, Signed at Warsaw on 12 October 1929, as Amended by the Protocol Done at the Hague on 28 September 1955, Signed at Montreal on 25 September 1975. Available from Internet: <http://www.dot.gov/ost/ogc/ProtocolNo4.pdf >.

Paulauskas, V.; Bentzen, K. 2008. Sea motorways as a part of the logistics chain, Transport 23(3): 202-207. doi:10.3846/1648-4142.2008.23.202-207

Protocol to Amend the International Convention for the Unification of Certain Rules of Law Relating to Bills of Lading Signed in Brussels on 25 August 1924 ('Visby Rules'). Brussels, 23 February 1968. Available from Internet: <http:// www.unidroit.info/mm/1968BrusselsProtocol.pdf $>$.

Report of the United Nations Commission on International Trade Law. 41 session, 16 June -3 July 2008. Available from Internet: <http://www.cmi2008athens.gr/sub3.9.pdf >.

Tetley, W. 2000. Uniformity of International Private Maritime Law - The Pros, Cons and Alternatives to International Conventions - How to Adopt an International Convention, Tulane Maritime Law Journal 24(1): 775-856.

Tetley, W. 2003. Reform of Carriage of Goods - the UNCITRAL Draft and Senate COGSA'99, Tulane Maritime Law Journal 28(1): 1-44.

The Hague-Visby Rules - The Hague Rules as Amended by the Brussels Protocol. 1968. Available from Internet: <http:// www.jus.uio.no/lm/sea.carriage.hague.visby.rules.1968/ portrait.pdf>.

Tolli, A.; Laving, J. 2007. Container transport direct call - Logistic solution to container transport via Estonia, Transport 22(4): Ia-If.

UNCTAD - United Nations Conference on Trade and Development. 2004. Carrier Liability and Freedom of Contract under the UNCITRAL Draft Instrument on the Carriage of Goods [Wholly or Partly] [By Sea]. Available from Internet: $<$ http://www.unctad.org/en/docs/sdtetlb20042_en.pdf>.

United Nations Convention on the Carriage of Goods by Sea (Hamburg Rules). 1978. Available from Internet: <http:// www.uncitral.org/pdf/english/texts/transport/hamburg/ XI_d_3_e.pdf $>$.

United Nations Convention on International Multimodal Transport of Goods. Geneva, 24 May 1980. Available from Internet: <http://www.jus.uio.no/lm/un.multimodal.transport.1980/portrait.pdf $>$.

United Nations Commission on International Trade Law (UNCITRAL). 2009. Available from Internet: <http://www.uncitral.org $>$.

United Nations Convention on Contracts for the International Carriage of Goods Wholly or Partly by Sea. 2009. Available from Internet: <http://www.uncitral.org/pdf/english/texts/ transport/rotterdam_rules/09-85608_Ebook.pdf >.

Vasilis Vasiliauskas, A.; Barysienè, J. 2008. An economic evaluation model of the logistic system based on container transportation, Transport 23(4): 311-315. doi:10.3846/1648-4142.2008.23.311-315 